\title{
Avulsion of the Levator Ani at First Pregnancy
}

\author{
Avulsi pada Levator Ani saat Kehamilan Pertama
}

\author{
Budi I. Santoso, Denny Khusen \\ Department of Obstetrics and Gynecology \\ Medical Faculty of Indonesia University/ \\ Dr. Cipto Mangunkusumo General Hospital \\ Jakarta
}

\begin{abstract}
Objective: To investigate whether demographic and obstetric risk factors are associated with avulsion of the levator ani at first pregnancy.

Methods: A series of case was undertaken on 4 pregnant nulliparous women seen with a gestational age of more than 37 weeks. We analyzed with 3D/4D translabial ultrasound and digital assessment data of 4 women seen in a tertiary Urogynecological clinic. The use of 3D/4D ultrasound as a means of detection of trauma to the levator ani.

Result: We had 4 women who had levator ani avulsion. Diagnosis of levator trauma (avulsion) on tomographic ultrasound was correlated with predelivery demographic variables and ultrasound parameters.

Conclusion: With a greater understanding on the function of pelvic floor muscles, risk factors for trauma and damage as a result of pregnancy and birth, healthcare professionals will have better ability to meet the needs of women in the childbearing year. This study utilized a scoring system that can be used to predict the occurrence of levator ani muscle damage. In the end, the decline in quality of life for women, especially after a birth, can be prevented.

[Indones J Obstet Gynecol 2013; 37-1: 51-6]

Keywords: 3D/4D translabial ultrasound, demographic, levator ani avulsion, obstetric risk factors
\end{abstract}

\begin{abstract}
Abstrak
Tujuan: Untuk mengetahui apakah faktor risiko demografi dan obstetri berhubungan dengan avulsi pada levator ani saat kehamilan pertama.

Metode: Serial kasus diambil dari 4 perempuan hamil nulipara dengan usia kehamilan lebih dari 37 minggu. Kami menganalisis dengan USG translabial 3D/4D dan data penilaian digital dari 4 perempuan tercatat di klinik Uroginekologi tersier. Penggunaan USG 3D/4D sebagai sarana deteksi trauma pada levator ani.

Hasil: Kami memiliki 4 perempuan yang mengalami avulsi pada levator ani. Diagnosis trauma (avulsi) levator pada USG tomografi berkorelasi dengan variabel demografi sebelum kelahiran dan parameter USG.

Kesimpulan: Dengan pemahaman yang lebih dalam pada fungsi otot dasar panggul, faktor risiko untuk trauma dan kerusakan sebagai akibat dari kehamilan dan kelahiran, tenaga kesehatan profesional akan memiliki kemampuan yang lebih baik untuk mengetahui kebutuhan perempuan di tahun melahirkan anak. Penelitian ini menggunakan sebuah sistem penilaian yang dapat digunakan untuk memprediksi terjadinya kerusakan pada otot levator ani. Pada akhirnya, penurunan kualitas hidup bagi perempuan, terutama setelah kelahiran, dapat dicegah.

[Maj Obstet Ginekol Indones 2013; 37-1: 51-6]

Kata kunci: avulsi pada levator ani, demografi, faktor risiko obstetri, USG translabial 3D/4D
\end{abstract}

Correspondence: Denny Khusen Department of Obstetrics and Gynecology, Medical Faculty of Indonesia University, Salemba Raya 6, Jakarta. Telephone: 085796252558. Email: dennyddk09@yahoo.com

\section{INTRODUCTION}

The levator ani muscle, in particular the puborectalis muscle which forms the levator hiatus, is thought to be of central importance for pelvic organ support and the maintenance of urinary and faecal continence. The prevalence of women who are pregnant for the first time to have avulsion of the levator ani is $2-7 \%$. Then the incidence avulsion of the levator ani muscle seems to occur in $15-30 \%$ of vaginally parous women. ${ }^{1,2}$ According to data, in United States alone more than 200,000 pregnant women at first pregnancy had avulsion of the levator ani, thus requiring surgery in labor which requires a higher cost. ${ }^{3-6}$
Levator ani muscle damage contributes greatly to the occurrence of pelvic floor dysfunction. Until very recently, the clinical relevance of such trauma is uncertain. Undoubtedly, there are many women who have suffered an avulsion injury without being in any way symptomatic of pelvic floor dysfunction. ${ }^{1}$ There are various risk factors affecting the levator ani muscle damage: the demographic, obstetric and gynecologic risk factors. ${ }^{7}$ Demographic risk factors include maternal age, race, parity, and body mass index. ${ }^{1,8,9}$ Obstetric risk factors include maternal age at first birth, mode of delivery, duration of second stage, the estimated fetal weight, episiotomy and lacerations vagina., 1,8,10 Gynecol- 
ogic risk factors include previous gynecologic surgery, menopausal status, use of hormone replacement therapy.

Gainey described an incidence of trauma to the pubococcygeus muscle of approximately $20-30 \%$ in primiparous women, with a preponderance of right sided trauma- exactly as we are observing today with the help of modern imaging methods. ${ }^{1}$

Pregnancy and childbirth is not only threatening the soul condition of the mother but also can cause damage to the pelvic floor muscles (levator ani) that ultimately lead to pelvic floor dysfunction. Pelvic floor dysfunction can cause various symptoms that interfere with quality of life such as inkontinensia urine, alvi, pelvic organ prolapse and sexual dysfunction. Recent magnetic resonance and ultrasound studies have shown major levator defects in $20-35 \%$ of vaginally parous women. No such defects have been found in women who delivered exclusively by caesarean section. ${ }^{6}$ Levator trauma (avulsion) is a strong risk factor for POP. Childbirth related trauma may involve not only the pelvic floor muscle but also damage to structures such as myofascial and connective tissue. ${ }^{7}$ Most studies evaluating the pelvic floor during pregnancy and following delivery focus on the impact of delivery on urinary or anal incontinence. ${ }^{8}$

But there has been no measurement of disability with respect to various risk factors that can be used to predict the levator ani muscle damage.

\section{METHODS}

A series of case was undertaken on 4 pregnant nulliparous women were recruited in the Dr. Cipto Mangunkusumo Hospital (RSCM) and other hospitals which became partners from June 2010 through December 2011. The inclusion criteria were nulliparous women with a gestational age of more than 37 weeks complete or more; the subject has undergone levator ani muscle avulsion prenatal; willing to be subjects in this study. The exclusion criteria was subjects with pregnancy complications, such as the location of latitude or antepartum hemorrhage.

Method sampling is done by using the consecutive method, that is every pregnant woman to complete 37 weeks of gestation or more who have met the study criteria to be included in the study sample.
Antenatal examination and abdominal ultrasound examination and ultrasound of the pelvic floor were performed on the respondents as the initial screening for the detection of levator ani muscle damage. Ultrasound examination was done in order to establish the diagnosis of levator ani muscle damage that occurs in this antenatal examination.

Translabial pelvic floor imaging is done using the 3D Voluson 730 Pro Ultrasound System transducer RAB 4-8 MHz. Before being placed in translabial, tranducer is wrapped with gloves or thin plastic to keep it hygienic. Do not use gloves that have been given the powder because it can damage the image quality because the gloves can cause unexpected resonance (reverberations). Imaging is performed while the patient is in dorsal lithotomy position (hip in flexion and slight abduction) or in a standing position after the bladder and rectum are being emptied. Transducer is placed translabial.

Examination steps of levator ani muscle by 3D ultrasound (Figure1):

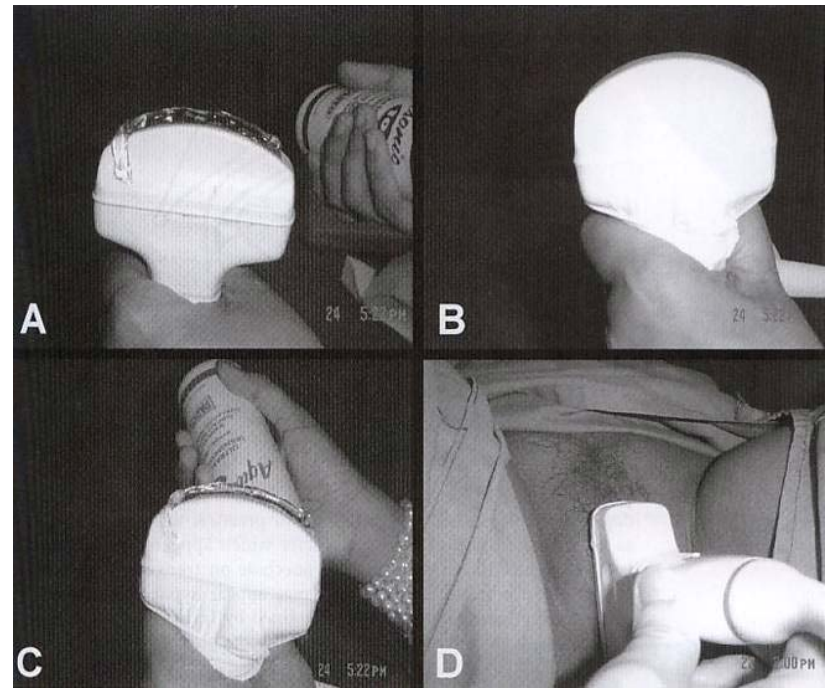

Figure 1. Preparing curve transducer for ultrasound translabial. After wetting the transducer with gel (A), the transducer is then coated with free-powder rubber gloves (B). Given additional gel (C) and then the transducer is placed on the perineum, between the labia majora (D). (Pictures with permission from Dr. Nelinda Pangilinan, Manila, Philippines).

Optimize images by adjusting the setting: the focus of two points, SRI 4, Xbeam CRI 2, turn on the "HI" to the normal frequency, image width using the maximum angle $90^{\circ}$. View 2D images, do positioning so that the symphysis pubis, vesica, vagina, anorectal up to levator ani are fit in the volume 
which will be displayed in 3D. The technique is: press the button on the trackball once so that the volume that will be in 3D is now made up of the dotted line so that the size can be changed. Move the trackball upwards to raise the volume, left and right to position the volume. Once the measure is complete, press button above the trackball once again to set the broad volume so that it will not change anymore. Then press the freeze button to run the 3D facility. Press the button to split the screen into 2 , so that the left side displays sagittal image piece, the right side displays the pelvic floor in 3D (rendered volume). Turn the 2D button to the left in order to darken the image a little bit so the picture of pelvic floor is more contrast. Consider the volume box on the left side, make sure the green box is located on the top side to make the axial cutting of pelvic floor. Shrink the size of volume box by pressing the button on the trackball once so that the box is now made up of dotted lines, move the trackball to the top so that the width of the box is reduced and create a width of $\pm 2 \mathrm{~cm}$. Press the button above the trackball twice so that the size does not change. Then move the trackball to move the sagittal images on the left screen, position so that the minimum hiatus plane is about a little below the edge lines of the green box. If the position is correct, hence on the right screen will be displayed the picture of the pelvic floor in 3D (volume rendered) clearly.

Instruct the patient to contract the levator ani muscle a minimum of twice, then press the freeze button. Press the save button in the form of movie so that the image of levator muscle contract twice is stored in the form of $4 \mathrm{D}$ (moving pictures). By moving the trackball to the left and right we can see moving pictures which had been stored and can choose the best moment of maximum contraction. Measure hiatus area by pressing the point area on the touchscreen and measure hiatus area by tracing along the edge of the hiatus, lastly press the button twice to give output result of the area that we trace. Activate the Tomographic Ultrasound Imaging (TUI) by selecting it via touchscreen, and then select plane $\mathrm{C}$, then turn the $\mathrm{Z}$ button to the left so that the image rotates $90^{\circ}$. Make sure that the TUI setting: the distance is $25 \mathrm{~mm} /$ pieces, number of pieces is 11 , the image can be enlarged by turning the zoom button. The system that describes the assessment of levator ani trauma after childbirth by measuring the Levator Urethra Gap (LUG) on three central pieces of the TUI.
Measure the distance on the left and right LUG on 3 central image of TUI. Note that if there is > $25 \mathrm{~mm}$ indicating levator avulsion. The levator muscle defects caused by trauma is defined when there is a LUG measurement $>25 \mathrm{~mm}$ on three central pieces of TUI, it shows positive results. Levator ani muscle defect is usually expressed as an avulsion of unilateral or bilateral avulsion. When finished, go back by pressing the rendered volume and init buttons on the touchscreen. Like when you first display the rendered volume but this time the patient is instructed strong straining at least twice and then measure the vast hiatus the same way as when patients contract the levator ani.

\section{RESULTS}

Table 1. Data of patients with levator ani avulsion

\begin{tabular}{lccc}
\hline \hline Education & Age & BMI & ANC Avulsion \\
\hline D3 & 26 & 18.75 & $(+)$ \\
D3 & 26 & 16.64 & $(+)$ \\
High school & 27 & 16.87 & $(+)$ \\
High school & 18 & 18.75 & $(+)$ \\
\hline \hline
\end{tabular}

Table caption: $B M I=B o d y$ Mass Index, $A N C=$ Antenatal care

We had 4 women who had levator ani avulsion. Diagnosis of levator trauma (avulsion) on tomographic ultrasound was correlated with predelivery demographic variables and ultrasound parameters.

Mean maternal age was 24.3 years (range, 1827). Mean BMI was 17,75 (range 16.64-18.75). From 182 patients, we checked on antenatal care, we found four patients with levator ani avulsion. We can explain the relationship between education and economic conditions that form a positive feedback. Socio-demographic factors will affect a person's nutritional status, meaning that if economic conditions get better the nutritional status will be better also. This will affect the body mass index to increase also.

\section{DISCUSSION}

Risk factors that could affect levator ani muscle damage consist of demographic and obstetric risk factors. Demographic risk factors include maternal age, race, parity, and body mass index while the 
obstetric risk factors include age of mother at first birth. A number of levator ani trauma mechanism was proposed, which include genetic predisposition associated with the properties of the collagen network, the mechanism strain of the pelvic floor, pelvic floor collagen tissue adaptation, and ultrastructural changes in vaginal tissue. ${ }^{11}$ If the pelvic floor has weakened, e.g. during vaginal delivery, the hiatus may not fully close anymore at contraction of the levator muscle. The counterforce will not come into effect, and POP may occur. ${ }^{11,12}$

Levator ani avulsion can be influenced by various factors. Race will have more influence on genetic conditions (genetic predisposition) and the factor of molecular biology. Genetic predisposition factors will affect the ability of the network adaptation and ultra structural changes. The relationship of tissue factor in the incidence of avulsion of the levator ani form a positive feedback or reinforcing loop. This can be interpreted if the adaptability of the network increases (getting better), the incidence of levator ani trauma will decrease. Furthermore, if the levator ani increased the incidence of a person's trauma then network adaptability will degrade. 8,10

By analogy, the above positive feedback can explain the relationship between education and economic conditions that form a positive feedback. Socio-demographic factors will affect a person's nutritional status, meaning that if economic conditions get better the nutritional status will be better also. This will affect the body mass index to increase also. Furthermore, body mass index increased the incidence of avulsion of the levator ani. 3,6

Old primi factor and duration of second stage of labor will affect the mechanisms of tissue strain on the pelvic floor muscles including levator ani. As a result, the mechanism of strain factor and the incidence of levator ani trauma will form a negative feedback. The higher the strain mechanism, the higher the levator ani trauma incidence. However, if the levator ani trauma increase as a result it will reduce the strain mechanism (the ability of the strain is reduced due to trauma). The relationship between second stage of labor and vaginal lacerations can be explained as follows: the higher the second stage of labor the higher the potential for vaginal lacerations. The same explanation used to explain the relationship between the variables birth weight, episiotomy, and laceration of the vagina and the incidence avulsion of the levator ani.
Old primi factors, stage II of labor, vaginal lacerations, episiotomy, and weight (baby) at birth, including the obstetric risk factors. ${ }^{7,8}$

It has been suggested that the hormonal effects of pregnancy may have an effect on levator ani muscle properties. ${ }^{13}$ Pregnancy is known to have negative effects on the integrity of the pelvic floor due to the influence of specific hormones that increase during pregnancy. Elevated levels of two hormones: progesterone and relaxin, especially will cause weakness of collagen tissue throughout the body. Influence of the hormones that cause dilation of blood vessels have also caused a greater mobility of joints, including joints in the pelvis, which causes a slight increase in diameter of the birth canal. These hormones also affect the collagen tissue of the pelvis, which causes weakness of ancillary structures from the vagina, bladder and rectum. ${ }^{11-16}$

The physiological changes occurring during pregnancy and the processes of childbirth have a detrimental effect on the structure and function of the muscles, nerves and fascial tissues (connective tissue) that make up the pelvic floor complex. As the fetus grows, the weight of the fetus and the gravid uterus (pregnant uterus) produce anatomical changes to the bladder and urethra. Studies using ultrasound imaging techniques have shown that the angle between the bladder neck and the urethra increases, producing an increased opening of the bladder neck. There is also an increased mobility of the bladder due to the hormonal changes of pregnancy which also affect the pelvic floor complex. ${ }^{17}$ Furthermore, it remains unclear whether pregnancy itself or factors associated with labor and delivery contribute to the injury of the pelvic floor. ${ }^{18}$

A long time has passed since Kegel first recommended pelvic floor muscle training to prevent and treat pelvic floor dysfunctions such as urinary incontinence (UI) and pelvic organ prolapse in women after child birth. Since then, randomized controlled trials have shown that antenatal pelvic floor muscle training also can prevent and treat UI both during pregnancy and in the immediate postpartum period. However, only a small proportion of pregnant women actually exercise the pelvic floor muscle regularly. ${ }^{19}$ This may be because women lack the knowledge and information about the possible positive effect of pelvic floor muscle training on UI. ${ }^{20}$ On the other hand, some health 
care providers claim that there is anecdotal evidence that elite athletes have rigid, inextensible pelvic floors that prolong the second stage of labor and that specific pelvic floor muscle training may make the pelvic floor muscle too strong and less elastic. ${ }^{21}$ Antenatal pelvic floor muscle training before and during pregnancy does not seem to affect labor and birth negatively. ${ }^{22}$ One study assessed pelvic floor muscle strength and found that it increased significantly after the 8-week training pe$\operatorname{riod}^{21}$

However, regular pelvic floor muscle training has been shown to increase pelvic floor muscle strength and muscle volume, to lift the levator plate into a higher pelvic position and to narrow the hiatus. ${ }^{23,24}$ All these factors potentially may prolong the total length of labor. It can be hypothesized that well-trained muscles may contribute to a reduced risk of injury during labor and may heal faster than untrained muscles. ${ }^{21}$

Previous studies investigating the use of estrogen as a therapy for prolapse have shown no effect on the stage of prolapse. In contrast, estrogen has been found to be therapeutic in the treatment of mild stress urinary incontinence and symptoms associated with urogenital atrophy. Estrogen receptors have been identified throughout the nuclei of the connective tissue and smooth muscle cells of the bladder trigone, urethra, vaginal mucosa, levator ani muscle stroma, the arcus tendineus, and the uterosacral ligament. If estrogen does positively impact the pelvic floor, it most likely acts in a preventative fashion to optimize the function of the pelvic floor muscle and connective tissue. ${ }^{7}$

An attempt to integrate various risk factors and to consider mechanisms of levator ani trauma. All efforts were done to eventually establish a scoring system that can be used to predict the occurrence of levator ani muscle damage. When scoring showed the risk of damage to the levator ani is low, then the patient can be convinced to choose a vaginal delivery without any sense of fear of pelvic floor dysfunction.

\section{CONCLUSION}

From this case series, we can learn that there are many complex factors that can cause avulsion of the levator ani. With a greater understanding on the function of the pelvic floor muscles and risk factors for trauma and damage as a result of preg- nancy and birth, healthcare professionals will have better ability to meet the needs of women in the childbearing year.

This study utilized a scoring system that can be used to predict the occurrence of levator ani muscle damage. Thus, it is expected that the decline in quality of life of women due to dysfunction of the pelvic floor after vaginal delivery can be prevented. Physicians were expected to become more aware of the women risks during pregnancy and able to provide a comprehensive choice of solutions. In the end, the decline in quality of life for women, especially after a birth, should be able to be prevented.

\section{REFERENCES}

1. Dietz HP. Levator trauma in Labor. A Challenge for Obstetricians, Surgeons and Sonologists. Ultrasound Obstet Gynecol 2007; 29:368-71.

2. DeLancey JO, Morgan DM, Fenner DE, Keamey R, Guire K, Miller JM, Hussain H, Umek W, Hsu Y, Ashton-Miller JA. Comparison of levator ani muscle defects and function in women with and without pelvic organ prolapse. Obstet Gynecol 2007; 109:295-302.

3. Dietz HP, Shek C. Levator avulsion and grading of pelvic floor muscle strength. Int Urogynecol J Pelvic Floor Dysfunct 2008; 19:633-6.

4. Buchsbaum GM, Duecy EE, Kerr LA, Huang LS, Perevich M, Guzick DS. Pelvic organ prolapse in nulliparous women and their parous sisters. Obstet Gynecol 2006; 108:1388-93.

5. Nikolova G, Lee H, Berkovitz S, Nelson S, Sinsheimer J, Vilain $\mathrm{E}$ et al. Sequence variant in the laminin gamma 1 (LAMC1) gene associated with familial pelvic organ prolapse. Hum Genetics 2007; 120:847-56.

6. Twiss C, Triaca V, Rodriguez LV. Familial transmission of urogenital prolapse and incontinence. Curr Opin Obstet Gynecol 2007; 19:464-8.

7. Moalli PA, Ivy SJ, Meyn LA, Zyczynski HM. Risk Factors Associated with Pelvic Floor Disorder in Women Undergoing Surgical Repair. Obstet Gynecol 2003; 101:869-74

8. Kearney R, Miller JM, Ashton-Miller JA, DeLancey JOL. Obstetric Factors associated with Levator Ani Muscle Injury after Vaginal Birth. Obstet Gynecol 2006; 107:144-9.

9. Viktrup L, Rortweit G, Lose G. Risk of Stress Urinary Incontinence Twelve Years after the First Pregnancy and Delivery. Obstet Gynecol 2006; 108:248-54.

10. Dietz HP. Quantification of Major Morphological Abnormalities of the Levator Ani. Ultrasound Obstet Gynecol 2007; 29:329-34

11. Kerkhof MH,Hendriks L, Brolmann HA. Changes in connective tissue in patients with pelvic organ prolapse a review of the current literature. Int Urogynecol J Pelvic Floor Dysfunct 2009; 20:461-74.

12. Shek KL, Dietz HP. Can levator avulsion be predicted antenatally? Am J Obstet Gynecol 2010; 202:586.

13. Dietz HP. Pelvic floor ultrasound: a review. Am J Obstet Gynecol 2010; 202:321-34. 
14. Jelovsek JE, Maher C, Barber MD. Pelvic organ prolapse. Lancet 2007; 369: 1027-38.

15. Schwetner-Tiepelmann N, Thakar R, Sultan AH, Turn R. Obstetric levator ani muscle injuries - Current status. Ultrasound Obstet Gynecol 2011.

16. Handa VL, Blomquist JL, McDermott KC, Friedman S, Munoz A. Pelvic floor disorders after vaginal birth: effect of episiotomy, perineal laceration, and operative birth. Obstet Gynecol 2012; 119:233-9.

17. Herbert J. Pregnancy and childbirth: the effect on pelvic floor muscles. Nurs Times 2009; 105:38-41.

18. O'Boyle AL, O'Boyle JD, Calhoun B, Davis GD. Pelvic organ support in pregnancy and postpartum. Int Urogynecol J Pelvic Floor Dysfunct 2005; 16:69-72.

19. Bo K, Haakstad L, Voldner N. Do pregnant women exercise their pelvic floor muscles? Int Urogynecol J Pelvic Floor Dysfunct 2007; 18:733-6.
20. McLennan MT, Melick CF, Alten B, Young J, Hoehn MR. Patients' knowledge of potential pelvic floor changes associated with pregnancy

21. Bo K, Fleten C, Nystad W. Effect of antenatal pelvic floor muscle training on labor and birth. Obstet Gynecol 2009; 113:1279-84.

22. Agur W, Steggles P, Waterfield M, Freeman R. Does antenatal pelvic floor training affect the outcome of labour? A randomised controlled trial. Int Urogynecol J Pelvic Floor Dysfunct 2008; 19:85-8.

23. Balmforth JR, Mantle J, Bidmead J, Cardozo L. A prospective observational trial of pelvic floor muscle training for female stress urinary incontinence. BJU Int 2006; 98:811-7.

24. Dumoulin C, Peng Q, Stodkilde-Jorgensen Shishido K, Constantinou C. Changes in levator ani anatomical configuration following physiotherapy in women with stress urinary incontinence. Urology 2007; 178:970-7. 